\title{
Circulating tumor cells in gastric cancer
}

\author{
Kenichi Nakamura1,2, Masaaki Iwatsuki², Junji Kurashige ${ }^{2}$, Takatsugu Ishimoto², Yoshifumi Baba², Yuji \\ Miyamoto $^{2}$, Naoya Yoshida², Masayuki Watanabe ${ }^{3}$, Hideo Baba ${ }^{2}$ \\ 'Division of Gastric Surgery, Shizuoka Cancer Center, Shizuoka 411-8777, Japan. \\ ${ }^{2}$ Department of Gastroenterological Surgery, Graduate School of Medical Sciences, Kumamoto University, Kumamoto \\ 860-8556, Japan. \\ ${ }^{3}$ Esophageal Cancer Division, Gastroenterological Surgery, Cancer Institute Hospital of Japanese Foundation for Cancer \\ Research, Tokyo 135-8550, Japan.
}

Correspondence to: Dr. Hideo Baba, Department of Gastroenterological Surgery, Graduate School of Medicine, Kumamoto University, 1-1-1 Honjo, Chuo-ku, Kumamoto 860-8556, Japan. E-mail: hdobaba@kumamoto-u.ac.jp

How to cite this article: Nakamura K, Iwatsuki M, Kurashige J, Ishimoto T, Baba Y, Miyamoto Y, Yoshida N, Watanabe M, Baba H. Circulating tumor cells in gastric cancer. J Cancer Metastasis Treat2018;4:32. http://dx.doi.org/10.20517/2394-4722.2017.78

Received: 21 Nov 2017 First Decision: 10 Feb 2018 Revised: 15 Feb 2018 Accepted: 6 Jun 2018 Published: 5 Jul 2018

Science Editors: Lucio Miele, Masayuki Watanabe Copy Editor: Jun-Yao Li Production Editor: Huan-Liang Wu

\begin{abstract}
Circulating tumor cells (CTCs) have received a lot of attention as a novel biomarker for cancer research in past decades. CTCs infiltrate the bloodstream derived from the primary tumor, and are significantly involved in cancer metastasis and recurrence. Although clinical applications have been challenging owing to the difficulties of CTC identification, recent development of technology for specific enrichment and detection of CTCs contributes to diagnosis and treatment. Furthermore, CTC analyses will shed new light on the biological mechanisms of cancer progression and metastasis. A number of clinical studies have already been carried out on the basis of CTC technology. Nevertheless, the clinical utility of CTCs is still unknown in gastric cancer. In this review, we elaborate on the latest advances of CTC research in gastric cancer.
\end{abstract}

Keywords: Circulating tumor cells, gastric cancer, cancer progression and metastasis, tumor heterogeneity, epithelial mesenchymal transition, cancer stem cells, immune check point blockade

\section{INTRODUCTION}

Gastric cancer is the sixth most common cancer and the third leading cause of cancer death worldwide ${ }^{[1]}$. Although diagnostic and therapeutic modalities for gastric cancer have been developed, it remains difficult to treat and manage patients with gastric cancer owing to the high frequency of metastasis and recurrence even after curative resection. Thus, to improve prognosis of gastric cancer, it is crucial to understand the process of metastasis and recurrence.

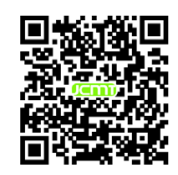


Cancer metastasis and recurrence have been conventionally diagnosed by imaging test or serum tumor marker; however, these modalities cannot provide a precise and timely assessment of the process of metastasis and recurrence. This process has been interpreted as involving the circulating tumor cells (CTCs), which are infiltrated into the bloodstream. The detection of CTCs was first described in $1869^{[2]}$, and the "seed and soil" hypothesis was proposed in $1889^{[3]}$. This hypothesis suggested that the dissemination of metastatic tumor cells was organ-specific and not simply anatomic. Because the isolation and detection of CTCs in the blood was technically difficult, the critical role of CTCs has finally been demonstrated more than a century $\operatorname{later}^{[4]}$. At last, recent technology has contributed to the diagnosis and treatment of various cancers. The utility of CTCs for early diagnosis, prediction of prognosis, monitoring of the response to anticancer drugs, and early detection of recurrence has been demonstrated in several types of human cancer ${ }^{[5-8]}$. Moreover, it is expected that the research of CTCs elucidates the biological mechanisms of cancer metastasis and leads to better understanding of tumor heterogeneity. However, the clinical significance of CTCs and its biology in gastric cancer remain controversial. In this article, we review the latest progress of CTCs in gastric cancer.

\section{CANCER METASTASIS AND CTCS}

Cancer metastasis is composed of several complex and interrelated steps, including transformation, migration, local invasion, intravasation into circulation, detachment, arrest at organs, extravasation, colonization, and proliferation. All steps are absolutely integral to the establishment of metastasis. In these processes, CTCs exhibit phenotypic diversity, such as epithelial mesenchymal transition (EMT) phenotype, and cancer stem cell (CSC) phenotype ${ }^{[9]}$, which facilitates metastasis.

EMT has been shown to play a critical role in metastatic spread by enhancing cancer cell mobility ${ }^{[10]}$. During EMT, epithelial cells change phenotype, such as reduction of cell-cell contacts, loss of polarity, development of cell mobility and invasiveness, repression of epithelial markers, and acquisition of mesenchymal phenotype. Epithelial markers [e.g., epithelial cells adhesion molecule (EpCAM), cytokeratin (CK), or E-cadherin] downregulate, while mesenchymal markers (e.g., vimentin, or N-cadherin) upregulate through EMT. Cancer cells undergoing EMT may intravasate as CTCs. Iwatsuki et al. ${ }^{[1]]}$ suggested that vimentinpositive tumor cells could survive in the peripheral circulation and the bone marrow and that vimentinpositive cancer cells invading intratumoral vessels must have undergone mesenchymal transition in gastric cancer. Furthermore, Wu et al. ${ }^{[12]}$ reported that mesenchymal CTCs detected by using EMT markers were more commonly found in patients with metastatic sites of several types of human cancers.

In the EMT process, cancer cells can acquire stem cell-like properties, such as self-renewal, tumor initiation, undifferentiated status, and treatment resistance ${ }^{[13]}$. CD44 has been reported as a representative marker of CSCs in gastric cancer ${ }^{[14]}$. It has been demonstrated that CD44-positive CTCs were associated with cancer progression and recurrence in gastric cancer ${ }^{[15]}$. A recent study revealed that CD44-positive CTCs decreased after surgery or chemotherapy; therefore, they may be a predictive marker of treatment response in gastric cancer $^{[16]}$.

\section{METHODOLOGY IN CTCS IDENTIFICATION}

CTC identification typically undergoes two processes of "enrichment" and "detection". The enrichment process is needed to detect CTCs efficiently, because CTCs are extremely rare, ranging between 1 to 10 cells per $10 \mathrm{~mL}$ in the peripheral blood ${ }^{[17]}$. CTCs can be enriched based on their biological and physical properties. Then, CTCs are detected using immunological, molecular, and functional assays [Table 1 and Figure 1$]^{[18]}$.

\section{Enrichment techniques}

Biological property-based techniques

The biological enrichment techniques are based on specific surface makers detected by antibodies. Epithelial 
Table 1. CTC enrichment and detection technologies

\begin{tabular}{llll}
\hline Method & System & \multicolumn{1}{c}{ Principle } & Limitations \\
\hline Enrichment technologies & & & \\
Biological & CellSearch & EpCAM antibodies coated with ferrofluid beads & Dependent on EpCAM \\
& AdnaTest & Immunomagnetic detection of EpCAM & High rate of false positive \\
& CTC-chip & EpCAM antibodies coated with microposts & Dependent on EpCAM \\
& MACS & Immunomagnetic beads coated with EpCAM antibodies & Dependent on EpCAM \\
& MagSweeper & Immunomagnetic beads coated with EpCAM antibodies & Depent on EpCAM \\
Physical & ISET & Size & Loss of CTCs \\
& OncoQuik & Density & Loss of CTCs \\
Retection technologies & RosetteSep & Density, negative selection & Limited throughput \\
Immunocytological & FACS & Antigen expression optical & Loss of CTCS \\
& FAST & Antigen expression optical & Loss of vibility \\
Folecular & FISH & Detects chromosomal DNA sequence & High rate of false positive \\
Functional assay & EPISPOT & Antigen expression & Enzymatic activity varies \\
\hline
\end{tabular}

CTC: circulating tumor cell; EpCAM: epithelial cells adhesion molecule; MACS: magnetic activated cell sorting; ISET: isolation by size of epithelial tumor; FACS: fluoroscence-assited cell sorting; FAST: fiber-optic array scanning technology; FISH: fluorescence in situ hybridization; RT-PCR: reverse transcription polymerase chain reaction; EPISPOT: epithelial immunospot



Figure 1. Circulating tumor cells (CTCS) enrichment (A-F) and detection (G-I) technologies. $A$ and $B$ : biological property-based techniques. A: positive selection - CTCs can be positively enriched using anti-epithelial or anti-mesenchymal marker antibody; B: negative selection - CTCs can be negatively enriched by depleting leukocyte using antibody against CD45. C-E: physical property-based techniques. C: filtration - CTCs are filtered using a membrane on the basis of the CTC size; D: chip - CTCs are trapped using microchip on the basis of CTC size and deformability; E: ficoll gradient centrifugation - CTCs are separated through a centrifugation on a ficoll density gradient on the basis of CTC density. F: physical and biological property-based techniques, CTC-chip - firstly, CTCs are selected on the basis of CTCs size, and then CTCs are isolated by magnetic bead-conjugated EpCAM antibodies, while normal hematopoietic cells are depleted by magnetic bead-conjugated antibodies against CD45. G: immunocytologial techniques - CTCs can be detected by using a combination of anti-epithelial, anti-mesenchymal, anti-tissue-specific marker, or anti-tumor-associated antibodies. H: molecular techniques - CTCs can be detected by using RNA-based technologies. I: functional assay - viable CTCs can be isolated by detecting secretion of specific tumor proteins from CTCs. MACS: magnetic activated cell sorting; FACS: fluoroscence-assited cell sorting; FAST: fiber-optic array scanning technology; FISH: fluorescence in situ hybridization; RT-PCR: reverse transcription polymerase chain reaction; EPISPOT: epithelial immunospot; EMT: epithelial mesenchymal transition 
cell markers are present on normal epithelial surface and epithelial tumors (i.e., carcinomas), but absent on normal blood cells; therefore, they can be used to identify the cancer cells in the bloodstream apart from normal blood cells. EpCAM and members of the CKs family (e.g., CK8, CK18, and CK19) are frequently used for positive selection of epithelial CTCs. However, epithelial cells can undergo EMT, resulting in downregulation of epithelial markers. To prevent false-negatives caused by EMT, N-cadherin and vimentin are used for identification of mesenchymal CTCs. In addition, to enrich CTCs specifically, negative selection is performed by using antibodies against CD45. CD45 is specifically expressed on the surface of leukocytes, whereas it is not expressed on carcinoma cells; thus, anti-CD45 antibody can deplete unnecessary leukocytes.

Tumor-specific makers, such as carcinoembryonic antigen (CEA), or $\alpha$-fetoprotein (AFP), are also used for biological CTC enrichment. In particular, human epidermal growth factor 2 (HER2) is suggested to be important biomarkers in the context of recent targeted therapies ${ }^{[19]}$.

On the basis of these techniques, there are various enrichment techniques. Magnetic activated cell sorting (MACS) uses magnetically labeled antibodies to enrich EpCAM-positive CTCs ${ }^{[20]}$. MagSweeper (Illumina, Hayward, CA, USA) is an automated immunomagnetic cell isolator for separation of rare endothelial cells $\mathrm{s}^{[2]}$.

CellSearch System ${ }^{\circ}$ (Veridex) captures CTCs using ferrofluid beads coated with anti-EpCAM antibody. Then, captured EpCAM-positive CTCs are stained with anti-CK and anti-CD45 fluorescently-conjugated dyes. Finally, enumeration of EpCAM-positive, CK-positive, and CD45-negative CTCs is completed by immunofluorescence ${ }^{[22]}$. The US Food and Drug Administration (FDA) has approved CellSearch for clinical use in breast, colorectal, and prostate cancer patients ${ }^{[6,23,24]}$. However, CTC detection by this system is not suitable for non-epithelial phenotype or EMT phenotype not expressing EpCAM and CK.

AdnaTest (AdnaGen AG, Langenhagen, Germany) is also an assay combining the enrichment and detection processes; that is, enriched by the magnetic procedure and detected by RT-PCR for identification of tumorassociated transcripts ${ }^{[25]}$.

CTC-chip is based on a microfluidic platform that contains an assortment of microposts coated with antiEpCAM antibodies. Whole blood is pumped through this chip and EpCAM-positive cells are isolated and detected by cameras identifying their morphology, viability and the expression of tumor markers ${ }^{[26]}$.

\section{Physical property-based techniques}

Other enrichment techniques depend on physical properties of CTCs, such as size, diameter, density, deformability, and electric charge. The tumor cells were previously thought to be larger $(>8 \mu \mathrm{m})$, and less deformable than blood cells. Isolation by size of epithelial tumor cells (ISET; RareCells, Paris, France) isolates epithelial cancer cells by using blood filtration with a membrane with $8 \mu \mathrm{m}$ pores; thus, larger cancer cells are filtered. ISET can detect a single CTC from $1 \mathrm{~mL}$ of peripheral blood ${ }^{[27]}$.

Density-dependent cell separation uses an inert polysucrose called Ficoll (GE Healthcare Bio-Science, Pittsburg, PA; BD Bioscience, San Jose, CA). Ficoll was originally developed to isolate intact mononuclear blood cells from whole blood. Oncoquick ${ }^{\text {mix }}$ (Greiner Bio One, Frickenhausen, Germany) based on Ficoll is a density gradient centrifugation system that can separate CTCs from whole blood samples ${ }^{[28]}$.

RosetteSep $^{\text {tw }}$ (StemCell Technologies, Vancouver, BC, Canada) is based on negative selection consisting of the depletion of the majority of the leukocytes and erythrocytes. This method employs a complex of antibodytargeted hematopoietic cells in human whole blood and crosslinks them to multiple erythrocytes, which leads to immunorosette formation. A centrifugation over a buoyant density medium such as Ficoll-Paque allows for the precipitation of immunorosettes and unbound red blood cells, while CTC fractions can be 
recovered from the medium.

Although cell filtration and centrifugation force have been investigated on the basis of these properties in past decades, it has been demonstrated that variations in CTC size have identified, and CTCs after undergoing EMT could be as deformable as leukocytes ${ }^{[2]}$. Therefore, new approaches have been developed to improve specificity of CTC enrichment.

\section{Detection techniques}

After CTC enrichment, CTCs are detected by many different assays. Recent CTC identification assays combine enrichment and detection processes (e.g., CellSearch System, ISET, AdnaTest, CTC-chip, and EPISPOT). Other detection technologies include immunocytological techniques, molecular techniques, and functional assays.

\section{Immunocytological techniques}

Immunocytological techniques detect CTCs using antibodies against various antigens. These provide characteristics with high accuracy and subpopulation quantification with high specificity for simultaneous analysis with multiple parameters. However, the drawback of these techniques is lower sensitivity compared with molecular techniques.

Fluoroscence-assited cell sorting (FACS) is widely used to separate a specific cell population by using antibodies. Since FACS can analyze many parameters simultaneously, it is a versatile method with a wide range of applications. FACS sorts each cell individually, meaning that throughput of FACS is limited. Moreover, sorting conditions may be harmful to certain types of cells ${ }^{[30]}$.

Fiber-optic array scanning technology (FAST; SRI International, Menlo Park, CA) can more efficiently analyze large numbers of immunofluorescent-labeled cells in peripheral blood. FAST applies laser-based techniques to scan broad fields of view, and can detect and characterize CTCs extremely quickly and accurately. As FAST can analyze larger volumes of peripheral blood, it does not require an additional enrichment step and reduces the risk of cell loss ${ }^{[31]}$.

Fluorescence in situ hybridization (FISH) can precisely detect specific DNA sequences within chromosomes by using fluorescent probes. However, FISH requires high proficiency, and sometimes cannot provide clear results. To overcome these problems, a novel technology named Ikoniscope (Ikonisis, New Haven, CT) was developed for rare cell detection ${ }^{[32]}$. This system can detect one CTC per milliliter of peripheral blood. However, cells no longer have viability after FISH; therefore this technology has limited application for analyzing CTC.

\section{Molecular techniques}

Quantitative reverse transcription polymerase chain reaction (qRT-PCR) can analyze the expression of specific markers in CTCs. Specificity of qRT-PCR has been reported to be superior to that of immunohistochemistry ${ }^{[33]}$. Nowadays, a multiplex RT-PCR approach combined with liquid bead array detection has been developed to perform simultaneous amplification and detection of multiple biomarkers. However, there are several limitations, such as the contamination of non-malignant cells, the high rate of false positives, and amplification of cell-free nucleic acids ${ }^{[34]}$. In addition, once RNA has been collected from cells, the cells cannot undergo advanced analysis.

\section{Functional assay}

Epithelial immunospot (EPISPOT) detects specific tumor marker proteins secreted by $\mathrm{CTCs}^{[35]}$. Only viable CTCs are detected by EPISPOT because non-viable CTCs are not enough to detect secretion of proteins. EPISPOT is much more sensitive than ELISA when detecting secretion of CK19 from CTCs ${ }^{[36]}$. However, 
because EPISPOT detects only CXCR4-positive CTCs, analysis of the heterogeneity of CTCs captured is limited.

While these developments can make CTC isolation accurate, further research on molecular characterization is necessary to confirm the significance of CTCs. Thus, the number of validation studies focusing on the characterization of CTCs has increased in recent years.

\section{CLINICAL UTILITY OF CTCS IN GASTRIC CANCER}

There have been many previous studies of CTCs in gastric cancer, as summarized in Table 2. Although there are various methodologies of CTCs identification (e.g., RT-PCR, FACS, CellSearch System), determining the most appropriate detection method and marker of CTCs in gastric cancer remains controversial. Several meta-analyses have demonstrated that the presence of CTC is associated with advanced clinicopathological features and poor survival in gastric cancer ${ }^{[37,38]}$. Huang et al ${ }^{[39]}$ indicated that CTCs was associated with advanced stage, undifferentiated histological type, lymphatic invasion positive, and poorer survival.

Furthermore, CTC detection has been suggested to be a useful biomarker of diagnosis. Although previous meta-analysis showed that CTC cannot be recommended as a screening test of gastric cancer owing to lower and inconsistent sensitivity estimates for CTCs, a recent study demonstrated that CTC detection based on FAST technique, in contrast to previous studies mainly based on RT-PCR, can be an available biomarker for early diagnosis of gastric cancer with high sensitivity and specificity ${ }^{[40]}$. In addition to diagnosis and prediction of prognosis, recent studies reported that monitoring changes of CTCs during treatment may be a predictive marker of response to treatment. Li et al. ${ }^{[41]}$ demonstrated that elevated CTCs $(\geq 3)$ during treatment were significantly associated with poor response rates and shorter survival. Notably, conversion to CTCs less than 3 after therapy improved the prognosis, while change to CTCs 3 or higher exhibited significantly worse prognosis. Shimazu et al. ${ }^{[42]}$ reported that gastric cancer with diffuse bone metastases might have a very high CTC count $(>200)$ in a small cohort. In cases with decrease of CTC count after treatment, tumor was sensitive to chemotherapy. They suggested that the change of CTC counts during treatment could be a predictive biomarker ${ }^{[42]}$.

HER2 has become a significant molecule for targeted therapy in gastric cancer. Trastuzumab (anti-HER2 monoclonal antibody) improved survival for patients with HER2 overexpressing gastric cancer. Although the assessment of HER2 status is usually performed on biopsy tissues from primary site, it has been reported that a discrepancy of HER2 status between the primary and the metastatic site was observed in some cases $^{[43]}$. There has been an attempt to use CTCs for reassessment of HER2 status in recurrence or metastatic sites $^{[44]}$. Mishima et al ${ }^{[45]}$ found a number of patients whose primary tumors were HER2 protein negative but who had HER2 gene positive CTCs by using 3D-FISH in gastric cancer. Furthermore, those patients had a favorable response to trastuzumab, and the second stage of the phase 2 trial is ongoing.

\section{FUTURE PERSPECTIVES}

\section{Heterogeneity of CTCs}

Tumor heterogeneity has been well-known to show genetic and phenotypic diversities between different tumor types, and within the same tumor and the same patient. It has been reported that heterogeneity was associated with the response and resistance to treatment ${ }^{[46]}$. Since the tumor heterogeneity changes throughout treatment, the serial profiling of disease is needed. However, there have been no diagnostic modalities or biomarkers available for timely and accurate assessment of heterogeneity. Therefore, much attention has been paid to monitoring dynamic changes of tumor heterogeneity during treatment by detecting CTCs, which is a minimally invasive and repeatable procedure, and may allow for reassessing the biology even in recurrence or metastasis. Scher et al. ${ }^{[47]}$ demonstrated that the degree of heterogeneity could 
Table 2. Clinical utilities of CTCs in gastric cancer

\begin{tabular}{|c|c|c|c|c|c|}
\hline Author & Year & Case & Method & $\begin{array}{l}\text { Molucular } \\
\text { marker }\end{array}$ & Clinical utility \\
\hline Wu et al. ${ }^{[53]}$ & 2006 & 64 & $\mathrm{MAH}$ & $\begin{array}{l}\text { TERT, CK19, } \\
\text { CEA, MUC }\end{array}$ & $\begin{array}{l}\text { The expression of all } 4 \text { mRNA markers was } \\
\text { an independent predictor for postoperative } \\
\text { recurrence/metastasis }\end{array}$ \\
\hline Uen et al. ${ }^{[54]}$ & 2006 & 52 & RT-PCR & MUC1, c-Met & $\begin{array}{l}\text { OS was shoter in patients with positive c-Met } \\
\text { or MUC1 mRNA expression than in patients } \\
\text { with negative c-Met or MUC1 }\end{array}$ \\
\hline Pituch-Noworolska et al.. & 2007 & 57 & ICC & CK8, 19, 20 & $\begin{array}{l}\text { There was no significant difference in the } \\
5 \text {-year survival of patients, with or without CK } \\
\text { in the blood }\end{array}$ \\
\hline Koga et al. ${ }^{[56]}$ & 2008 & 101 & RT-PCR & CK18, 19, 20 & $\begin{array}{l}\text { CK19 was a better marker than CK18 and } \\
\text { CK20, and could be clinically useful to } \\
\text { estimate prognosis }\end{array}$ \\
\hline Yie et al. ${ }^{[57]}$ & 2008 & 55 & RT-PCR, ELISA & Survivin & $\begin{array}{l}\text { Survivin-expressing CTCs were statistically } \\
\text { shown to be a significant and independent } \\
\text { predictor for cancer recurrence }\end{array}$ \\
\hline Mimori et al. ${ }^{[58]}$ & 2008 & 810 & RT-PCR & $\begin{array}{l}\text { CK7, 19, 20, } \\
\text { VEGFR }\end{array}$ & $\begin{array}{l}\text { Elevated expression of VEGFR-1 was } \\
\text { associated with hematogenous metastases in } \\
\text { gastric cancer }\end{array}$ \\
\hline Bertazza et al. ${ }^{[59]}$ & 2009 & 70 & RT-PCR & Survivin & $\begin{array}{l}\text { Survivin mRNA levels were retained as an } \\
\text { independent prognostic factor }\end{array}$ \\
\hline Qiu et al. ${ }^{[60]}$ & 2010 & 123 & RT-PCR & CEA & $\begin{array}{l}\text { CEA mRNA positivity were independent } \\
\text { factors for DFS }\end{array}$ \\
\hline Arigami et al. ${ }^{[61]}$ & 2010 & 94 & RT-PCR & $\mathrm{B} 7-\mathrm{H} 3$ & $\begin{array}{l}\text { The } 5 \text {-year OS rate was significantly lower in } \\
\text { patients with than without B7-H4 expression }\end{array}$ \\
\hline Matsusaka et al. ${ }^{[62]}$ & 2010 & 52 & CellSearch & $\begin{array}{l}\text { EpCAM, CK8, } \\
18,19\end{array}$ & $\begin{array}{l}\text { Patients with U } 4 \text { CTCs at 2-week points and } \\
\text { 4-week points after initiation of chemotherapy } \\
\text { had a shorter median PFS }\end{array}$ \\
\hline Cao et al. ${ }^{[63]}$ & 2011 & 98 & RT-PCR, ELISA & Survivin & $\begin{array}{l}\text { The detection of CTCs expressing survivin } \\
\text { mRNA was an independent prognostic factors } \\
\text { of DFS }\end{array}$ \\
\hline Ito et al. ${ }^{[64]}$ & 2012 & 65 & ICC & GFP, EpCAM & $\begin{array}{l}\text { There was a significant relationship between } \\
\text { the number of GFP-positive CTCs and overall } \\
\text { survival }\end{array}$ \\
\hline Arigami et $a{ }^{[65]}$ & 2013 & 93 & RT-PCR & STC2 & $\begin{array}{l}\text { The 5-year OS rate was significantly lower in } \\
\text { patients with STC } 2 \text { expressioncompared to } \\
\text { patients without STC2 expression }\end{array}$ \\
\hline Uenosono et $a{ }^{[66]}$ & 2013 & 148 & CellSearch & $\begin{array}{l}\text { EpCAM, CK8, } \\
18,19\end{array}$ & $\begin{array}{l}\text { The detection of CTCs was an indepentdent } \\
\text { factor of shorter OS and PFS }\end{array}$ \\
\hline Okabe et al. ${ }^{[67]}$ & 2015 & 136 & CellSearch & $\begin{array}{l}\text { EpCAM, CK8, } \\
18,19\end{array}$ & $\begin{array}{l}\text { The detection of CTCs was an indepentdent } \\
\text { factor of shorter PFS }\end{array}$ \\
\hline Lee et al. ${ }^{[68]}$ & 2015 & 100 & CellSearch & $\begin{array}{l}\text { EpCAM, CK8, } \\
18,19\end{array}$ & $\begin{array}{l}\text { The detection of CTCs was associated with } \\
\text { poor response to chemotherapy in metastatic } \\
\text { gastric cancer }\end{array}$ \\
\hline Kubisch et al. ${ }^{[69]}$ & 2015 & 62 & $\begin{array}{l}\text { Immune- } \\
\text { magnetic }\end{array}$ & MUC1, EpCAM & $\begin{array}{l}\text { The detection of CTCs was associated with } \\
\text { shorter PFS and OS for patients undergoing } \\
\text { chemotherapy }\end{array}$ \\
\hline Li et al. ${ }^{[70]}$ & 2016 & 136 & CellSearch & $\begin{array}{l}\text { EpCAM, CK8, } \\
18,19\end{array}$ & $\begin{array}{l}\text { Conversion to a favourable CTC level }(<3 \\
\text { CTCs per } 7.5 \mathrm{~mL}) \text { following therapy improved } \\
\text { the prognosis }\end{array}$ \\
\hline
\end{tabular}

MAH: membrane-array hybridization; ICC: immunocytochemistry; ELISA: enzyme-linked immunosorbent assay; DFS: disease free survival; OS: overall survival; PFS: progression free survival; CTC: circulating tumor cell; EpCAM: epithelial cells adhesion molecule; RTPCR: reverse transcription polymerase chain reaction

serve as a biomarker of therapy option.

Furthermore, the advances in single-cell technologies have enabled individual CTC characterization, leading to improved understanding about tumor heterogeneity. Alix-Panabières and Pantel ${ }^{[48]}$ reviewed genomic, transcriptomic, and proteomic characterization of single CTCs in different cancer types, and suggested that analysis of single CTCs may play a key role in understanding the mechanism of resistance to cancer therapy. 


\section{PD-L1 expression on CTCs}

Immune check point blockade with programmed cell-death protein 1 (PD-L1) inhibitor has recently attracted attention as a novel anticancer approach for treatment of advanced cancers. Overexpression of PDL1 has been considered a potential mechanism of tumor escape immune elimination ${ }^{[49]}$. PD-L1 inhibitors are currently being most actively investigated for clinical use in various cancers. PD-L1 expression has been evaluated by mainly immunohistochemistry for primary tumor site as a predictive biomarker of response. However, recent studies reported tumor heterogeneity in both primary and distant metastatic site ${ }^{[50]}$.

CTCs survive in the bloodstream by exploiting immune escape mechanisms, including immune check point molecule. Therefore, it is crucial to understand the interaction of CTCs with the immune system to utilize more effective immunotherapies. Mazel et al. ${ }^{[51]}$ demonstrated that PD-L1 frequently upregulated in CTCs of metastatic breast cancer patients. Furthermore, Strati $e$ al $^{[52]}$ showed that the detection of CTCs overexpressing $P D-L 1$ mRNA at the end of treatment was associated with poor survival, and the absence of $P D-L 1$ overexpression at the end of treatment was related with complete response in head and neck squamous cell carcinoma.

\section{CONCLUSION}

Although there are many studies focusing on the utility of CTCs for diagnosis, prediction, monitoring, and choosing therapy, CTCs have not been used yet in clinical practice for gastric cancer. Therefore, further investigation and clinical studies are necessary to achieve clinical utility of CTC in gastric cancer.

\section{DECLARATIONS}

\section{Authors' contributions}

Wrote the initial draft of the manuscript: Nakamura K

Contributed to interpretation of data, and assisted in the preparation of the manuscript: Iwatsuki $\mathrm{M}$

Contributed to data collection and interpretation, and critically reviewed the manuscript: Kurashige J, Ishimoto T, Baba Y, Miyamoto Y, Yoshida N, Watanabe M, Baba H

\section{Availability of data and materials}

Not applicable.

\section{Financial support and sponsorship}

None.

\section{Conflicts of interest}

There are no conflicts of interest.

\section{Ethical approval and consent to participate}

Not applicable.

\section{Consent for publication}

Not applicable.

\section{Copyright}

(c) The Author(s) 2018.

\section{REFERENCES}

1. Global Burden of Disease Cancer Collaboration; Fitzmaurice C, Allen C, Barber RM, Barregard L, Bhutta ZA, Brenner H, Dicker DJ, Chimed-Orchir O, Dandona R, Dandona L, Fleming T, Forouzanfar MH, Hancock J, Hay RJ, Hunter-Merrill R, Huynh C, Hosgood HD, 
Johnson CO, Jonas JB, Khubchandani J, Kumar GA, Kutz M, Lan Q, Larson HJ, Liang X, Lim SS, Lopez AD, MacIntyre MF, Marczak L, Marquez N, Mokdad AH, Pinho C, Pourmalek F, Salomon JA, Sanabria JR, Sandar L, Sartorius B, Schwartz SM, Shackelford KA, Shibuya K, Stanaway J, Steiner C, Sun J, Takahashi K, Vollset SE, Vos T, Wagner JA, Wang H, Westerman R, Zeeb H, Zoeckler L, Abd-Allah F, Ahmed MB, Alabed S, Alam NK, Aldhahri SF, Alem G, Alemayohu MA, Ali R, Al-Raddadi R, Amare A, Amoako Y, Artaman A, Asayesh H, Atnafu N, Awasthi A, Saleem HB, Barac A, Bedi N, Bensenor I, Berhane A, Bernabé E, Betsu B, Binagwaho A, Boneya D, Campos-Nonato I, Castañeda-Orjuela C, Catalá-López F, Chiang P, Chibueze C, Chitheer A, Choi JY, Cowie B, Damtew S, das Neves J, Dey S, Dharmaratne S, Dhillon P, Ding E, Driscoll T, Ekwueme D, Endries AY, Farvid M, Farzadfar F, Fernandes J, Fischer F, G/Hiwot TT, Gebru A, Gopalani S, Hailu A, Horino M, Horita N, Husseini A, Huybrechts I, Inoue M, Islami F, Jakovljevic M, James S, Javanbakht M, Jee SH, Kasaeian A, Kedir MS, Khader YS, Khang YH, Kim D, Leigh J, Linn S, Lunevicius R, El Razek HMA, Malekzadeh R, Malta DC, Marcenes W, Markos D, Melaku YA, Meles KG, Mendoza W, Mengiste DT, Meretoja TJ, Miller TR, Mohammad KA, Mohammadi A, Mohammed S, Moradi-Lakeh M, Nagel G, Nand D, Le Nguyen Q, Nolte S, Ogbo FA, Oladimeji KE, Oren E, Pa M, Park EK, Pereira DM, Plass D, Qorbani M, Radfar A, Rafay A, Rahman M, Rana SM, Søreide K, Satpathy M, Sawhney M, Sepanlou SG, Shaikh MA, She J, Shiue I, Shore HR, Shrime MG, So S, Soneji S, Stathopoulou V, Stroumpoulis K, Sufiyan MB, Sykes BL, Tabarés-Seisdedos R, Tadese F, Tedla BA, Tessema GA, Thakur JS, Tran BX, Ukwaja KN, Uzochukwu BSC, Vlassov VV, Weiderpass E, Wubshet Terefe M, Yebyo HG, Yimam HH, Yonemoto N, Younis MZ, Yu C, Zaidi Z, Zaki MES, Zenebe ZM, Murray CJL, Naghavi M. Global, regional, and national cancer incidence, mortality, years of life lost, years lived with disability, and disability-adjusted life-years for 32 cancer groups, 1990 to 2015: a systematic analysis for the global burden of disease study. JAMA Oncol 2017;3:524-48.

2. Ashworth TR. A case of camcer in which cells to similar to those in the tumours were seen in the blood after death. Australas Med J 1869;14:146-9.

3. Paget G. Remarks on a case of alternate partial anaesthesia. Br Med J 1889;1:1-3.

4. Fidler IJ. The pathogenesis of cancer metastasis: the 'seed and soil' hypothesis revisited. Nat Rev Cancer 2003;3:453-8.

5. Scher HI, Jia X, de Bono JS, Fleisher M, Pienta KJ, Raghavan D, Heller G. Circulating tumour cells as prognostic markers in progressive, castration-resistant prostate cancer: a reanalysis of IMMC38 trial data. Lancet Oncol 2009;10:233-9.

6. Cristofanilli M, Budd GT, Ellis MJ, Stopeck A, Matera J, Miller MC, Reuben JM, Doyle GV, Allard WJ, Terstappen LW, Hayes DF. Circulating tumor cells, disease progression, and survival in metastatic breast cancer. N Engl J Med 2004;351:781-91.

7. Krebs MG, Sloane R, Priest L, Lancashire L, Hou JM, Greystoke A, Ward TH, Ferraldeschi R, Hughes A, Clack G, Ranson M, Dive C, Blackhall FH. Evaluation and prognostic significance of circulating tumor cells in patients with non-small-cell lung cancer. J Clin Oncol 2011;29:1556-63.

8. Cohen SJ, Punt CJ, Iannotti N, Saidman BH, Sabbath KD, Gabrail NY, Picus J, Morse M, Mitchell E, Miller MC, Doyle GV, Tissing H, Terstappen LW, Meropol NJ. Relationship of circulating tumor cells to tumor response, progression-free survival, and overall survival in patients with metastatic colorectal cancer. J Clin Oncol 2008;26:3213-21.

9. Iwatsuki M, Kurashige J, Ishimoto T, Kosumi K, Baba Y, Sakamoto Y, Miyamoto Y, Yoshida N, Watanabe M, Baba H. The clinical significance of circulating tumor cells in gastrointestinal cancer. J Cancer Metastasis Treat 2015;1:130-7.

10. Yang J, Weinberg RA. Epithelial-mesenchymal transition: at the crossroads of development and tumor metastasis. Dev Cell 2008;14:81829.

11. Iwatsuki M, Mimori K, Fukagawa T, Ishii H, Yokobori T, Sasako M, Baba H, Mori M. The clinical significance of vimentin-expressing gastric cancer cells in bone marrow. Ann Surg Oncol 2010;17:2526-33.

12. Wu S, Liu S, Liu Z, Huang J, Pu X, Li J, Yang D, Deng H, Yang N, Xu J. Classification of circulating tumor cells by epithelial-mesenchymal transition markers. PLoS One 2015;10:e123976.

13. O'Brien CA, Pollett A, Gallinger S, Dick JE. A human colon cancer cell capable of initiating tumour growth in immunodeficient mice. Nature 2007;445:106-10.

14. Takaishi S, Okumura T, Tu S, Wang SS, Shibata W, Vigneshwaran R, Gordon SA, Shimada Y, Wang TC. Identification of gastric cancer stem cells using the cell surface marker CD44. Stem Cells 2009;27:1006-20.

15. Li M, Zhang B, Zhang Z, Liu X, Qi X, Zhao J, Jiang Y, Zhai H, Ji Y, Luo D. Stem cell-like circulating tumor cells indicate poor prognosis in gastric cancer. Biomed Res Int 2014;2014:981261.

16. Toyoshima K, Hayashi A, Kashiwagi M, Hayashi N, Iwatsuki M, Ishimoto T, Baba Y, Baba H, Ohta Y. Analysis of circulating tumor cells derived from advanced gastric cancer. Int J Cancer 2015;137:991-8.

17. Ross AA, Cooper BW, Lazarus HM, Mackay W, Moss TJ, Ciobanu N, Tallman MS, Kennedy MJ, Davidson NE, Sweet D. Detection and viability of tumor cells in peripheral blood stem cell collections from breast cancer patients using immunocytochemical and clonogenic assay techniques. Blood 1993;82:2605-10.

18. Alix-Panabières C, Pantel K. Challenges in circulating tumour cell research. Nat Rev Cancer 2014;14:623-31.

19. Pestrin M, Bessi S, Puglisi F, Minisini AM, Masci G, Battelli N, Ravaioli A, Gianni L, Di Marsico R, Tondini C, Gori S, Coombes CR, Stebbing J, Biganzoli L, Buyse M, Di Leo A. Final results of a multicenter phase II clinical trial evaluating the activity of single-agent lapatinib in patients with HER2-negative metastatic breast cancer and HER2-positive circulating tumor cells. A proof-of-concept study. Breast Cancer Res Treat 2012;134:283-9.

20. Carroll S, Al-Rubeai M. ACSD labelling and magnetic cell separation: a rapid method of separating antibody secreting cells from nonsecreting cells. J Immunol Methods 2005;296:171-8.

21. Talasaz AH, Powell AA, Huber DE, Berbee JG, Roh KH, Yu W, Xiao W, Davis MM, Pease RF, Mindrinos MN, Jeffrey SS, Davis RW. Isolating highly enriched populations of circulating epithelial cells and other rare cells from blood using a magnetic sweeper device. Proc Natl Acad Sci U S A 2009;106:3970-5.

22. Racila E, Euhus D, Weiss AJ, Rao C, McConnell J, Terstappen LW, Uhr JW. Detection and characterization of carcinoma cells in the blood. Proc Natl Acad Sci U S A 1998;95:4589-94.

23. Negin BP, Cohen SJ. Circulating tumor cells in colorectal cancer: past, present, and future challenges. Curr Treat Options Oncol 2010;11:1- 
13 .

24. Resel Folkersma L, Olivier Gómez C, San José Manso L, Veganzones de Castro S, Galante Romo I, Vidaurreta Lázaro M, de la Orden GV, Arroyo Fernández M, Díaz Rubio E, Silmi Moyano A, Maestro de Las Casas MA. Immunomagnetic quantification of circulating tumoral cells in patients with prostate cancer: clinical and pathological correlation. Arch Esp Urol 2010;63:23-31.

25. Andreopoulou E, Yang LY, Rangel KM, Reuben JM, Hsu L, Krishnamurthy S, Valero V, Fritsche HA, Cristofanilli M. Comparison of assay methods for detection of circulating tumor cells in metastatic breast cancer: AdnaGen AdnaTest BreastCancer Select/Detect versus Veridex CellSearch system. Int J Cancer 2012;130:1590-7.

26. Nagrath S, Sequist LV, Maheswaran S, Bell DW, Irimia D, Ulkus L, Smith MR, Kwak EL, Digumarthy S, Muzikansky A, Ryan P, Balis UJ, Tompkins RG, Haber DA, Toner M. Isolation of rare circulating tumour cells in cancer patients by microchip technology. Nature 2007;450:1235-9.

27. Vona G, Sabile A, Louha M, Sitruk V, Romana S, Schütze K, Capron F, Franco D, Pazzagli M, Vekemans M, Lacour B, Bréchot C, Paterlini-Bréchot P. Isolation by size of epithelial tumor cells: a new method for the immunomorphological and molecular characterization of circulatingtumor cells. Am J Pathol 2000;156:57-63.

28. Rosenberg R, Gertler R, Friederichs J, Fuehrer K, Dahm M, Phelps R, Thorban S, Nekarda H, Siewert JR. Comparison of two density gradient centrifugation systems for the enrichment of disseminated tumor cells in blood. Cytometry 2002;49:150-8.

29. Nedosekin DA, Juratli MA, Sarimollaoglu M, Moore CL, Rusch NJ, Smeltzer MS, Zharov VP, Galanzha EI. Photoacoustic and photothermal detection of circulating tumor cells, bacteria and nanoparticles in cerebrospinal fluid in vivo and ex vivo. J Biophotonics 2013;6:523-33.

30. Arnold LW, Lannigan J. Practical issues in high-speed cell sorting. Curr Protoc Cytom 2010; Chapter 1:Unit 1.24.1-30.

31. Krivacic RT, Ladanyi A, Curry DN, Hsieh HB, Kuhn P, Bergsrud DE, Kepros JF, Barbera T, Ho MY, Chen LB, Lerner RA, Bruce RH. A rare-cell detector for cancer. Proc Natl Acad Sci U S A 2004;101:10501-4.

32. Ntouroupi TG, Ntouroupi TG, Ashraf SQ, McGregor SB, Turney BW, Seppo A, Kim Y, Wang X, Kilpatrick MW, Tsipouras P, Tafas T, Bodmer WF. Detection of circulating tumour cells in peripheral blood with an automated scanning fluorescence microscope. Br J Cancer 2008;99:789-95.

33. Smith BM, Slade MJ, English J, Graham H, Lüchtenborg M, Sinnett HD, Cross NC, Coombes RC. Response of circulating tumor cells to systemic therapy in patients with metastatic breast cancer: comparison of quantitative polymerase chain reaction and immunocytochemical techniques. J Clin Oncol 2000;18:1432-9.

34. Kowalewska M, Chechlińska M, Markowicz S, Kober P, Nowak R. The relevance of RT-PCR detection of disseminated tumour cells is hampered by the expression of markers regarded as tumour-specific in activated lymphocytes. Eur J Cancer 2006;42:2671-4.

35. Alix-Panabières C, Vendrell JP, Pellé O, Rebillard X, Riethdorf S, Müller V, Fabbro M, Pantel K. Detection and characterization of putative metastatic precursor cells in cancer patients. Clin Chem 2007;53:537-9.

36. Alix-Panabières C, Vendrell JP, Slijper M, Pellé O, Barbotte E, Mercier G, Jacot W, Fabbro M, Pantel K. Full-length cytokeratin-19 is released by human tumor cells: a potential role in metastatic progression of breast cancer. Breast Cancer Res 2009;11:R39.

37. Wang S, Zheng G, Cheng B, Chen F, Wang Z, Chen Y, Wang Y, Xiong B. Circulating tumor cells (CTCs) detected by RT-PCR and its prognostic role in gastric cancer: a meta-analysis of published literature. PLoS One 2014;9:e99259.

38. Zou K, Yang S, Zheng L, Wang S, Xiong B. Prognostic role of the circulating tumor cells detected by cytological methods in gastric cancer: a meta-analysis. Biomed Res Int 2016;2016:2765464.

39. Huang X, Gao P, Sun J, Chen X, Song Y, Zhao J, Xu H, Wang Z. Clinicopathological and prognostic significance of circulating tumor cells in patients with gastric cancer: a meta-analysis. Int J Cancer 2015;136:21-33.

40. Kang HM, Kim GH, Jeon HK, Kim DH, Jeon TY, Park DY, Jeong H, Chun WJ, Kim MH, Park J, Lim M, Kim TH, Cho YK. Circulating tumor cells detected by lab-on-a-disc: role in early diagnosis of gastric cancer. PLoS One 2017;12:e0180251.

41. Li Y, Gong J, Zhang Q, Lu Z, Gao J, Li Y, Cao Y, Shen L. Dynamic monitoring of circulating tumour cells to evaluate therapeutic efficacy in advanced gastric cancer. Br J Cancer 2016;114:138-45.

42. Shimazu K, Fukuda K, Yoshida T, Inoue M, Shibata H. High circulating tumor cell concentrations in a specific subtype of gastric cancer with diffuse bone metastasis at diagnosis. World J Gastroenterol 2016;22:6083-8.

43. Gumusay O, Benekli M, Ekinci O, Baykara M, Ozet A, Coskun U, Demirci U, Uner A, Dursun A, Atak EY, Buyukberber S. Discordances in HER2 status between primary gastric cancer and corresponding metastatic sites. Jpn J Clin Oncol 2015;45:416-21.

44. Iwatsuki M, Toyoshima K, Watanabe M, Hayashi N, Ishimoto T, Eto K, Iwagami S, Baba Y, Yoshida N, Hayashi A, Ohta Y, Baba H. Frequency of HER2 expression of circulating tumour cells in patients with metastatic or recurrent gastrointestinal cancer. Br J Cancer 2013;109:2829-32.

45. Mishima Y, Matsusaka S, Chin K, Mikuniya M, Minowa S, Takayama T, Shibata H, Kuniyoshi R, Ogura M, Terui Y, Mizunuma N, Hatake K. Detection of HER2 amplification in circulating tumor cells of HER2-negative gastric cancer patients. Target Oncol 2017;12:341-51.

46. Burrell RA, McGranahan N, Bartek J, Swanton C. The causes and consequences of genetic heterogeneity in cancer evolution. Nature 2013;501:338-45.

47. Scher HI, Graf RP, Schreiber NA, McLaughlin B, Jendrisak A, Wang Y, Lee J, Greene S, Krupa R, Lu D, Bamford P, Louw JE, Dugan L, Vargas HA, Fleisher M, Landers M, Heller G, Dittamore R. Phenotypic heterogeneity of circulating tumor cells informs clinical decisions between AR signaling inhibitors and taxanes in metastatic prostate cancer. Cancer Res 2017;77:5687-98.

48. Alix-Panabières C, Pantel K. Characterization of single circulating tumor cells. FEBS Lett 2017;591:2241-50.

49. Mohme M, Riethdorf S, Pantel K. Circulating and disseminated tumour cells - mechanisms of immune surveillance and escape. Nat Rev Clin Oncol 2017;14:155-67.

50. Jilaveanu LB, Shuch B, Zito CR, Parisi F, Barr M, Kluger Y, Chen L, Kluger HM. PD-L1 expression in clear cell renal cell carcinoma: an analysis of nephrectomy and sites of metastases. J Cancer 2014;5:166-72.

51. Mazel M, Jacot W, Pantel K, Bartkowiak K, Topart D, Cayrefourcq L, Rossille D, Maudelonde T, Fest T, Alix-Panabières C. Frequent 
expression of PD-L1 on circulating breast cancer cells. Mol Oncol 2015;9:1773-82.

52. Strati A, Koutsodontis G, Papaxoinis G, Angelidis I, Zavridou M, Economopoulou P, Kotsantis I, Avgeris M, Mazel M, Perisanidis C, Sasaki C, Alix-Panabières C, Lianidou E, Psyrri A. Prognostic significance of PD-L1 expression on circulating tumor cells in patients with head and neck squamous cell carcinoma. Ann Oncol 2017;28:1923-33.

53. Wu CH, Lin SR, Hsieh JS, Chen FM, Lu CY, Yu FJ, Cheng TL, Huang TJ, Huang SY, Wang JY. Molecular detection of disseminated tumor cells in the peripheral blood of patients with gastric cancer: evaluation of their prognostic significance. Dis Markers 2006;22:103-9.

54. Uen YH, Lin SR, Wu CH, Hsieh JS, Lu CY, Yu FJ, Huang TJ, Wang JY. Clinical significance of MUC1 and c-Met RT-PCR detection of circulating tumor cells in patients with gastric carcinoma. Clin Chim Acta 2006;367:55-61.

55. Pituch-Noworolska A, Kolodziejczyk P, Kulig J, Drabik G, Szczepanik A, Czupryna A, Popiela T, Zembala M. Circulating tumour cells and survival of patients with gastric cancer. Anticancer Res 2007;27:635-40.

56. Koga T, Tokunaga E, Sumiyoshi Y, Oki E, Oda S, Takahashi I, Kakeji Y, Baba H, Maehara Y. Detection of circulating gastric cancer cells in peripheral blood using real time quantitative RT-PCR. Hepatogastroenterology 2008;55:1131-5.

57. Yie SM, Lou B, Ye SR, Cao M, He X, Li P, Hu K, Rao L, Wu SM, Xiao HB, Gao E. Detection of survivin-expressing circulating cancer cells (CCCs) in peripheral blood of patients with gas- tric and colorectal cancer reveals high risks of relapse. Ann Surg Oncol 2008;15:307382.

58. Mimori K, Fukagawa T, Kosaka Y, Kita Y, Ishikawa K, Etoh T, Iinuma H, Sasako M, Mori M. Hematogenous metastasis in gastric cancer requires isolated tumor cells and expression of vascular endothelial growth factor receptor-1. Clin Cancer Res 2008;14:2609-16.

59. Bertazza L, Mocellin S, Marchet A, Pilati P, Gabrieli J, Scalerta R, Nitti D. Survivin gene levels in the peripheral blood of patients with gastric cancer independently predict survival. J Transl Med 2009;7:111.

60. Qiu MZ, Li ZH, Zhou ZW, Li YH, Wang ZQ, Wang FH, Huang P, Aziz F, Wang DY, Xu RH. Detection of carcinoembryonic antigen messenger RNA in blood using quantitative real-time reverse transcriptase-polymerase chain reaction to predict recurrence of gastric adenocarcinoma. J Transl Med 2010;8:107.

61. Arigami T, Uenosono Y, Hirata M, Yanagita S, Ishigami S, Natsugoe S. B7-H3 expression in gastric cancer: a novel molecular blood marker for detecting circulating tumor cells. Cancer Sci 2011;102:1019-24.

62. Matsusaka S, Suenaga M, Mishima Y, Kuniyoshi R, Takagi K, Terui Y, Mizunuma N, Hatake K. Circulating tumor cells as a surrogate marker for determining response to chemotherapy in Japanese patients with metastatic colorectal cancer. Cancer Sci 2011;102:1188-92.

63. Cao W, Yang W, Li H, Lou G, Jiang J, Geng M, Xi W, Ren R, Qu Q, Jin X, Zhu Y, Jin Y. Using detection of survivin-expressing circulating tumor cells in peripheral blood to predict tumor recurrence following curative resection of gastric cancer. J Surg Oncol 2011;103:110-5.

64. Ito H, Inoue H, Sando N, Kimura S, Gohda K, Sato J, Murakami K, Ito S, Odaka N, Satodate H, Kudo SE. Prognostic impact of detecting viable circulating tumour cells in gastric cancer patients using a telomerase-specific viral agent: a prospective study. BMC Cancer 2012;12:346.

65. Arigami T, Uenosono Y, Ishigami S, Yanagita S, Hagihara T, Haraguchi N, Matsushita D, Hirahara T, Okumura H, Uchikado Y, Nakajo A, Hokita S, Natsugoe S. Clinical significance of stanniocalcin 2 expression as a predictor of tumor progression in gastric cancer. Oncol Rep 2013;30:2838-44.

66. Uenosono Y, Arigami T, Kozono T, Yanagita S, Hagihara T, Haraguchi N, Matsushita D, Hirata M, Arima H, Funasako Y, Kijima Y, Nakajo A, Okumura H, Ishigami S, Hokita S, Ueno S, Natsugoe S. Clinical significance of circulating tumor cells in peripheral blood from patients with gastric cancer. Cancer 2013;119:3984-91.

67. Okabe H, Tsunoda S, Hosogi H, Hisamori S, Tanaka E, Tanaka S, Sakai Y. Circulating tumor cells as an independent predictor of survival in advanced gastric cancer. Ann Surg Oncol 2015;22:3954-61.

68. Lee SJ, Lee J, Kim ST, Park SH, Park JO, Park YS, Lim HY, Kang WK. Circulating tumor cells are predictive of poor response to chemotherapy in metastatic gastric cancer. Int J Biol Markers 2015;30:e382-6.

69. Kubisch I, de Albuquerque A, Schuppan D, Kaul S, Schaich M, Stölzel U. Prognostic role of a multimarker analysis of circulating tumor cells in advanced gastric and gastroesophageal adenocarcinomas. Oncology 2015;89:294-303.

70. Li Y, Gong J, Zhang Q, Lu Z, Gao J, Li Y, Cao Y, Shen L. Dynamic monitoring of circulating tumour cells to evaluate therapeutic efficacy in advanced gastric cancer. Br J Cancer 2016;114:138-45. 